\title{
Seroprevalence of Enterically Transmitted Hepatitis Viruses in Patients Attending a Tertiary Care Hospital in Maharashtra, India
}

\author{
Suvarna Vaibhav Sande ${ }^{1}$ \\ ${ }^{1}$ Department of Microbiology, Jawaharlal Nehru Medical College, Datta Meghe Institute of Medical Sciences \\ (Deemed to Be University) Sawangi, Wardha, Maharashtra, India.
}

\section{ABSTRACT}

\section{BACKGROUND}

Hepatitis A \& E viruses are enterically transmitted viruses responsible for acute viral hepatitis in developing countries. Hepatitis A virus (HAV) has worldwide distribution while hepatitis E virus (HEV) is restricted to tropical countries. HAV affects infants and young children while HEV affects older children and young adults. This study was conducted to determine the seroprevalence of HAV and HEV and their co-infection in patients presenting with acute viral hepatitis (AVH).

\section{METHODS}

200 sera of patients suffering from suspected acute viral hepatitis (AVH) attending tertiary care rural hospital JNMC Sawangi, Wardha were included in the study. Serum samples were tested for IgM anti HAV and IgM anti - HEV for the detection of acute hepatitis A and acute hepatitis E using commercially available ELISA kit \& Immunochromatography test (ICT) for comparison of ELISA and ICT.

\section{RESULTS}

The overall seroprevalence of HAV and HEV infection was found to be $19 \%$. The seroprevalence of HAV infection was found to be $13 \%$, HEV infection $5 \%$ and HAV HEV co - infection $1 \%$. HAV infection in males and females was found to be $16.07 \%$ and $9.09 \%$ respectively \& HEV infection was found to be $5.35 \%$ and $4.54 \%$ respectively. In case of detection of HAV IgM, two serum samples were negative by ICT but positive by ELISA \& for HEV IgM, one serum sample was negative by ICT but positive by ELISA. The sensitivity, specificity, positive predictive value and negative predictive value of HAV IgM was found to be $96 \%, 98.8 \%, 92.30 \%$ \& $99.43 \%$ and for HEV IgM was found to be $90 \%, 99.47 \%, 90 \%$ \& $99.47 \%$ respectively.

\section{CONCLUSIONS}

It is evident from this study that infection with enteric hepatitis viruses is not infrequent. Findings from this study emphasize the need to establish regular seroepidemiological surveys to keep track of epidemiology of these viruses. Results from rapid tests are comparable to ELISA with additional advantage of ease of interpretation and neither time consuming nor requiring special instruments.
Corresponding Author: Dr. Suvarna Sande, Professor, Department of Microbiology, Jawaharlal Nehru Medical College, Datta Meghe Institute of Medical Sciences, (Deemed To Be University) Sawangi, Wardha, Maharashtra, India. E-mail: suvarnasande@yahoo.co.in

DOI: $10.14260 / j e m d s / 2021 / 472$

How to Cite This Article:

Sande SV. Seroprevalence of enterically transmitted hepatitis viruses in patients attending a tertiary care hospital in Maharashtra, India. J Evolution Med Dent Sci 2021;10(30):2310-2313, DOI: $10.14260 / \mathrm{jemds} / 2021 / 472$

Submission 17-03-2021,

Peer Review 21-05-2021,

Acceptance 27-05-2021,

Published 26-07-2021.

Copyright (c) 2021 Suvarna Vaibhav Sande. This is an open access article distributed under Creative Commons Attribution License [Attribution 4.0 International (CC BY 4.0)]

\section{KEY WORDS}

Hepatitis A, Hepatitis E, Seroprevalence 


\section{BACKGROUND}

Viral hepatitis is inflammation of the liver due to viral infection. Common five viral agents responsible for hepatitis are hepatitis A virus (HAV), hepatitis B virus (HBV), hepatitis $C$ virus (HCV), the HBV-associated delta agent or hepatitis D virus (HDV) and hepatitis E virus (HEV). Hepatitis B, C, D viruses are transmitted parentally while Hepatitis $A$ and $E$ are transmitted by the faecal - oral route. Feco oral transmission is generally seen in poor personal hygiene and unsanitary conditions. Hence Hepatitis A and E are more common in developing countries with serious health consequences. ${ }^{1,2}$ Hepatitis A and E have short incubation period (15 - 60 days). Hepatitis A affects mainly young age group (infants and young children) while $\mathrm{E}$ affects any age group. (Mainly older children and young adults). In pregnant women, Hepatitis E can induce fulminating acute disease. There is no carrier stage or progression to liver cancer in both enterically transmitted viral infections. ${ }^{2,3}$ There are about 1.4 million new cases of HAV throughout the world annually. ${ }^{3}$ Hepatitis A virus is a single-stranded positive-sense RNA virus having diameter of $27-32 \mathrm{~nm}$, belonging to family Picornaviridae and genus Hepatovirus. During acute illness, there will be increased serum aminotransferase activity, faecal HAV shedding, and one can detect anti HAV IgM antibodies. Hepatitis A presents as self- limiting disease that does not lead to chronic condition. 4,5 The initial antibody to appear is IgM that lasts for several months (approximately 3 months, sometimes 6 - 12 months) followed by IgG response. Both IgG and IgM can be detected by HAV total antibody test which can be used to assess present or past infection and test for immunity prior to vaccination. 6

Hepatitis E virus (HEV) is $32-34 \mathrm{~nm}$, single-stranded, positive sense RNA virus with 7200 - nucleotide and belongs to family Hepeviridae and genus Hepevirus. Irrespective of genomic heterogeneity up to $25 \%$ and presence of four genotypes (genotypes 1 to 4) all HEV isolates appear to belong to single serotype. Among four genotypes, genotypes 1 and 2 are more virulent, while genotypes 3 and 4 appear to be less virulent and are responsible for subclinical illness. ${ }^{7,8} \mathrm{HEV}$ infection has two distinct epidemiological patterns in humans. The HEV1 and HEV2 genotypes are generally spread in humans via the faecal-oral route, commonly through polluted water, in areas with unsanitary conditions and poor hygiene. It is usually a self-limiting disease that persists for few weeks and occasionally results in recurrent sporadic cases and major outbreaks. ${ }^{9}$ The scenario in developed countries depicted that, genotypes HEV3 and HEV4 were mostly spread zoonotically from animal reservoirs, with sporadic cases. Furthermore, HEV 3 infection induces chronic illness with rapidly progressive cirrhosis in immunocompromised patients. (Organ transplant patients, blood dyscrasias, patients undergoing chemotherapy and HIV patients etc. $)^{7,9}$ Two ways of HEV infection diagnosis are indirectly through detection of serum anti-HEV antibodies, while directly by presence of specific HEV RNA in blood or other body fluids. After the incubation period of $2-6$ weeks an initial short lived IgM response is followed by longer lasting IgG antibodies. Anti HEV IgM is considered as a marker of current illness while, anti-HEV IgG alone is an indicator of past infection. ${ }^{10,11}$

\section{METHODS}

This cross-sectional study was conducted in the Department of Microbiology, JNMC, Wardha for a period of six months from January to June 2018 after getting approval from Institutional Ethics Committee. Total 200 sera of patients of all ages and both sexes of suspected acute viral hepatitis attending our hospital were included in this study.

\section{Sample Size}

To calculate sample size, open EPI software was used. Based on findings from previous study ${ }^{12}$ (IgM anti HAV positive 7 out of 306) about seroprevalence of enterically transmitted hepatitis, the sample size was calculated as 196 expecting $5 \%$ margin of error and confidence interval of $90 \%$. The sample size was rounded off to 200 .

\section{Viral Serology}

Serum samples were tested for acute hepatitis A and hepatitis E by testing for IgM anti HAV and IgM anti - HEV antibodies by commercially available ELISA kits as per manufacturer's instruction. (DIA.PRO - diagnostic Bioprobes, Italy). Same set of samples were tested in parallel using Immuno chromatograhy test (ICT) (SD bioline for HAV IgM and Insight for HEV IgM) for comparison of ELISA and ICT.

\section{Statistical Analysis}

Statistical analysis was carried out by statistical methods like positive predictive value, negative predictive value, sensitivity and specificity.

\section{RESULTS}

Total 200 serum samples from patients suffering from suspected acute viral hepatitis (AVH) were processed for HAV and HEV IgM by ELISA test. Out of 200 serum samples, seroprevalence of HAV and HEV infection was found to be 19 $\%$. Number of samples from male and female patients were 112 and 88 respectively. HAV IgM was detected in 26 (13\%) samples, HEV IgM in 10 (5\%) samples and both HAV and HEV IgM in 2 (1\%) samples by ELISA test. $16.07 \%$ males and 9.09 $\%$ females showed HAV infection while $5.35 \%$ males and 4.54 $\%$ females showed HEV infection. In HAV and HEV coinfection, both cases were males. (Table 1)

\begin{tabular}{|cccc|}
\hline $\begin{array}{c}\text { Hepatitis A \& E } \\
\text { Antibodies }\end{array}$ & Male (N = 112) & $\begin{array}{c}\text { Female }(\mathbf{N}= \\
\mathbf{8 8})\end{array}$ & Total $(\mathbf{N}=\mathbf{2 0 0})$ \\
HAV IgM & $18(16.07 \%)$ & $8(9.09 \%)$ & $26(13 \%)$ \\
HEV IgM & $6(5.35 \%)$ & $4(4.54 \%)$ & $10(5 \%)$ \\
HAV IgM + HEVIgM & $2(1.78 \%)$ & - & $2(1 \%)$ \\
\hline Table 1. HAV and HEV IgM Positive Cases by ELISA \\
- & Sex Wise Distribution \\
\hline \multicolumn{4}{|c}{} \\
\hline
\end{tabular}

The seroprevalence of Anti HAV and Anti HEV antibodies according to age is shown in Table 2. The anti HAV prevalence was more in the age group of 11 - 20 years followed by 21 - 30 years whereas only one case was detected in $>50$ years' age group. The anti HEV prevalence was more in age group 21 - 30 
years. There was no statistically significant difference between the age groups for anti HAV and anti HEV antibodies.

\begin{tabular}{|cccccccc|}
\hline $\begin{array}{c}\text { Age Group } \\
\text { (Years) }\end{array}$ & $\begin{array}{c}\text { Total } \\
\text { Cases }\end{array}$ & \multicolumn{2}{c}{ HAV IgM+ } & \multicolumn{2}{c|}{ HEV IgM+ } & \multicolumn{2}{c|}{$\begin{array}{c}\text { HAV IgM + HEV } \\
\text { IgM Positive }\end{array}$} \\
$0-10$ & 22 & 2 & 1 & - & - & - & - \\
$11-20$ & 56 & 6 & 2 & - & 1 & 1 & - \\
$21-30$ & 49 & 4 & 2 & 2 & 2 & 1 & - \\
$31-40$ & 32 & 3 & 2 & 2 & 1 & - & - \\
$41-50$ & 24 & 2 & 1 & 1 & 0 & - & - \\
$>50$ & 17 & 1 & 0 & 1 & - & - & - \\
Total & $\mathbf{2 0 0}$ & $\mathbf{1 8}$ & $\mathbf{8}$ & $\mathbf{6}$ & $\mathbf{4}$ & $\mathbf{2}$ & - \\
\hline \multicolumn{7}{c}{ Table 2. HAV and HEV IgM Positive Cases by ELISA Test } \\
- Age Wise Distribution \\
\hline
\end{tabular}

\begin{tabular}{|ccc|}
\hline & ELISA & ICT \\
\hline HAV IgM & 26 & 24 \\
HEV IgM & 10 & 9 \\
HAV+HEV IgM & 2 & 1 \\
& 38 & 34 \\
\hline Table 3(a). Comparison between ELISA Test and ICT \\
\hline
\end{tabular}

\begin{tabular}{|ccccc|}
\hline \multirow{2}{*}{ ELISA } & \multicolumn{2}{c}{ HAV IgM Test } & \multicolumn{2}{c|}{ HEV IgM Test } \\
& Positive & Negative & Positive & Negative \\
positive & 24 & 2 & 9 & 1 \\
Negative & 01 & 176 & 01 & 191 \\
\hline \multicolumn{2}{|c|}{ Table } & 3(b). Comparison between ELISA and ICT \\
\hline
\end{tabular}

In present study, in case of detection of HAV IgM, two serum samples were negative by ICT but positive by ELISA. [Table 3(b)] One sample was positive by ICT but negative by ELISA. In case of detection of HEV IgM, one serum sample was negative by ICT but positive by ELISA. One sample was positive by ICT but negative by ELISA. In case of co-infection, out of 2 cases, only one case of coinfection was identified by ICT while ELISA identified both cases. The sensitivity, specificity, positive predictive value and negative predictive value of HAV IgM was found to be $96 \%, 98.8 \%, 92.30 \%$ \& $99.43 \%$ respectively and that of HEV IgM was found to be $90 \%, 99.47$ $\%, 90 \%$ \& $99.47 \%$ respectively. (Table 4 )

\begin{tabular}{|ccc|}
\hline & HAV IgM Rapid Test & HEV IgM Rapid Test \\
Sensitivity & $96 \%$ & $90 \%$ \\
Specificity & $98.8 \%$ & $99.47 \%$ \\
Positive predictive value & $92.30 \%$ & $90 \%$ \\
Negative predictive value & $99.43 \%$ & $99.47 \%$ \\
\hline Table 4. Sensitivity, Specificity, Positive Predictive Value and Negative \\
Predictive Value of HAV IGM Rapid Test and HEV IGM Rapid Test \\
\hline
\end{tabular}

\section{DISCUSSION}

In the present study, only $19 \%$ of the suspected cases of acute viral hepatitis had a positive viral marker for hepatitis A or hepatitis E. This is in accordance with study by Joon ${ }^{9}$ where prevalence of HAV and HEV was found to be $11.5 \%$. In the present study, $13 \%$ samples were positive for HAV IgM only, $5 \%$ for HEV IgM only. This is in accordance with study by Joon et al. ${ }^{9}$ where prevalence of HAV was found to be $13.25 \%$, HEV $5.21 \%$. In study by Saumya Agrawal ${ }^{1}$, seroprevalence of HAV was found to be $15.5 \%$, HEV somewhat higher i.e. $27.2 \%$.

Various studies have reported a varying prevalence ranging from $1.7 \%$ to $67 \%$ for $\mathrm{HAV}$ and $12.6 \%$ to $78.6 \%$ for HEV.13,14,15,16 Such wide variation in positivity could be due to differences in the study population, standards of hygiene and sanitation and type of samples - whether sporadic or from outbreaks. Variation may also occur with manufacturer's lot of the diagnostic testing kits. ${ }^{13,14,15}$
In the present study, the seroprevalence of HAV - HEV coinfection was $1 \%$ which is similar to that reported by Das et al. ${ }^{17}$ from Northeast India and Mittal et al. ${ }^{12}$ from Rajasthan.

In the present study, seroprevalence of HAV in males and females was found to be $16.07 \%$ and $9.09 \%$ respectively. A male preponderance of HAV infection was also observed by Kamal et al. ${ }^{18}$ and by $\mathrm{Al}-\mathrm{Naaimi}$ et $\mathrm{al} .{ }^{19} \mathrm{~A}$ possible explanation for this male preponderance could be greater exposure of males to their professional and social activities. However, Kuntz and Kuntz ${ }^{20}$ reported that irrespective of race, age and seasonal or regional factors, men and women are subjected to the same frequency of infection.

Seroprevalance of HEV in males and females was found to be $5.35 \%$ and $4.54 \%$ respectively but this difference was not statistically significant. Similar studies by Joonet al. ${ }^{9}$ Kamal et al. ${ }^{18}$ and $\mathrm{Al}-$ Naaimi et al. ${ }^{19}$ observed a greater prevalence in males as compared to females in case of HEV infection. However, Nikfar et al.21 reported that no clear gender predilection exists for hepatitis E infection.

In the present study, maximum cases of HAV infection was found in the age group of $11-20$ years. This is comparable to study by Junoo et al. ${ }^{9}$ but in contrast to study by Saumya agrawal ${ }^{10}$ where higher number of cases of HAV infection was found in age under 10 years. In present study, maximum number of cases of HEV infection was found in age group of 21 - 30 years which is in accordance with study by G. Modi et al. ${ }^{22}$ and Saumya Agrawal et al. ${ }^{10}$

In the present study, in case of detection of HAV IgM, two serum samples were negative by ICT but positive by ELISA. A negative result can occur in ICT if the quantity of IgM anti hepatitis A virus present in the specimen is below the detection limits of the assay. ${ }^{19}$ One sample was positive by ICT but negative by ELISA. In case of detection of HEV IgM, one serum sample was negative by ICT but positive by ELISA. One sample was positive by ICT but negative by ELISA. In case of coinfection, out of 2 cases, only one case of coinfection was identified by ICT while ELISA identified both cases. The sensitivity, specificity, positive predictive value and negative predictive value of HAV IgM was found to be $96 \%, 98.8$ $\%, 92.30 \%$ \& $99.43 \%$ respectively and that of HEV IgM was found to be $90 \%, 99.47 \%, 90 \%$ \& $99.47 \%$ respectively. ICT has advantage like simple to use, no need of special instruments, easy to interpret and has high sensitivity and specificity. ${ }^{23}$

\section{Limitations}

In present study sample size was small (200 samples) and study was of short duration (6 months). Studies involving large sample size and longer duration to know about seroprevalence of Hepatitis A and Hepatitis E will be more appropriate.

\section{CONCLUSIONS}

Despite being limited to small sample size, it is inferred from this study that infection with hepatitis A and E viruses is not uncommon. Findings from this study emphasize the need to establish regular seroepidemiological surveys to keep track of epidemiology of these viruses. HEV infection is not rare and its 
presence should be properly investigated. Additional studies having large sample size are needed for incidence and severity of health problems associated with enterically transmitted viral hepatitis in developing countries. Results from rapid tests are comparable to ELISA with additional advantage of ease of interpretation with neither time consuming nor requiring special instruments.

Data sharing statement provided by the authors is available with the full text of this article at jemds.com.

Financial or other competing interests: None.

Disclosure forms provided by the authors are available with the full text of this article at jemds.com.

Author is thankful to DMIMS (DU) for help while conducting this study.

\section{REFERENCES}

[1] Irshad M, Singh S, Ansari MA, et al. Viral hepatitis in India: a report from Delhi. Glob J Health Sci 2010;2(2):96-103.

[2] Radhakrishnan S, Raghuraman S, Abraham P, et al. Prevalence of enterically transmitted hepatitis viruses in patients attending a tertiary-care hospital in South India. Indian J Pathol Microbiol 2000;43(4):433-6.

[3] Franco E, Meleleo C, Serino L, et al. Hepatitis A: epidemiology and prevention in developing countries. World J Hepatol 2012;4(3):68-73.

[4] Holiinger FB, Suzanne UE. Hepatitis A virus. In: David MK, Peter $\mathrm{MH}$, eds. Fields Virology. PA, USA: Lippincott Williams \& Wilkins 2001:801-40.

[5] Stephen MF, Ian DG. Hepatitis A virus. In: Douglas DR, Richard JW, Frederick GH, et al, eds. $2^{\text {nd }}$ edn. Clinical Virology. USA: ASM Press 2002:1022-23.

[6] Hadem J, Manns MP. Immune response to hepatitis A and E viruses. In: Gershwin ME, Vierling JM, Manns MP, eds. Liver Immunology. New Jersey: Humana Press 2007:16377.

[7] Tahaei SME, Mohebbi SR, Zali MR. Enteric hepatitis viruses. Gastroenterol Hepatol 2012;5(1):7-15.

[8] Khuroo MS, Kamili S. Aetiology, clinical course and outcome of sporadic acute viral hepatitis in pregnancy. J Viral Hepat 2003;10(1):61-9.

[9] Joon A, Rao P, Shenoy SM, et al. Prevalence of Hepatitis A Virus (HAV) and Hepatitis E Virus (HEV) in the patients presenting with acute viral hepatitis. Indian J Med Microbiol 2015;33(Suppl 1):102-5.

[10] Agrawal S, Anuradha SA, Sahoo AB, et al. Seroprevalence of Hepatitis A Virus (HAV) and Hepatitis E Virus (HEV) coinfection in patients presenting with acute viral hepatitis attending a tertiary care hospital in North India. J Commun Dis 2017;49(3):57-60.

[11] Huang S, Zhang X, Jiang H, et al. Profile of acute infectious markers in sporadic hepatitis E. PLoS One 2010;5(10):e13560.

[12] Mittal A, Bithu R, Vyas N, et al. Prevalence of hepatitis A virus and hepatitis $E$ virus in the patients presenting with acute viral hepatitis at a tertiary care hospital Jaipur Rajasthan. N Niger J Clin Res 2016;5(8):47-50.

[13] Kaur R, Gur R, Berry N, et al. Etiology of endemic viral hepatitis in urban North India. Southeast Asian J Trop Med Public Health 2002;33(4):845-8.

[14] Das K, Agarwal A, Andrew R, et al. Role of hepatitis E and other hepatotropic virus in aetiology of sporadic acute viral hepatitis: a hospital based study from urban Delhi. Eur J Epidemiol 2000;16(10):937-40.

[15] Chadha MS, Walimbe AM, Chobe LP, et al. Comparison of etiology of sporadic acute and fulminant viral hepatitis in hospitalized patients in Pune, India during 1978-81 and 1994-97. Indian J Gastroenterol 2003;22(1):11-5.

[16] Sarguna P, Rao A, Ramana KNS. Outbreak of acute viral hepatitis due to hepatitis E virus in Hyderabad. Indian J Med Microbiol 2007;25(4):378-82.

[17] Das AK, Ahmed S, Medhi S, et al. Changing patterns of aetiology of acute sporadic viral hepatitis in India-Newer insights from North-East India. Int J Cur Res Rev 2014;6(19):14-20.

[18] Kamal SM, Mahmoud S, Hafez T, et al. Viral hepatitis a to be in South Mediterranean countries. Mediterr J Hematol Infect Dis 2010;2(1):e2010001.

[19] Al-Naaimi AS, Turky AM, Khaleel HA, et al. Predicting acute viral hepatitis serum markers (A and $E$ ) in patients with suspected acute viral hepatitis attending primary health care centers in Baghdad: a one year cross-sectional study. Glob J Health Sci 2012;4(5):172-83.

[20] Kuntz E, Kuntz HD. Hepatology: Textbook and Atlas. 3rd edn. Heidelberg, Germany: Springer Verlag Berlin 2008.

[21] Shamsizadeh A, Nikfar R, Makvandi $M$, et al. Seroprevalence of hepatitis E virus infection in children in the Southwest of Iran. Hepatitis Monthly 2009;9(4):2614.

[22] Modi GB, Patel HS. Seroprevalence of Hepatitis E virus at Palanpur in North Gujarat. Saudi J Pathol Microbiol 2018;3(10):348-50.

[23] Posthuma-Trumpie GA, Korf J, Van Amerongen A. Lateral flow (immuno) assay: its strengths, weaknesses, opportunities and threats. A literature survey. Anal Bioanal Chem 2009;393(2):569-82. 